Original Research Paper

\title{
Effect of Input Production Against Quality of Cocoa Beans
}

\author{
Effendy and Made Antara \\ Department of Agriculture Economics, Tadulako University, Indonesia
}

\section{Article history}

Received: 31-08-2015

Revised: $10-09-2015$

Accepted: 16-10-2015

Corresponding Author:

Effendy

Department of Agriculture

Economics, Tadulako

University, Indonesia

Email: effendy_surentu@yahoo.com

\begin{abstract}
This research aims to: (1) analyze the effect of input production against total beans per $100 \mathrm{~g}$ of dry cocoa beans and (2) analyze the correlation of total beans and fat content of cocoa beans. The Cobb-Douglas production function assisted in answering the first goal, while correlation analysis provided a means to answer the second. Results showed that: (1) urea fertilizers, $\mathrm{KCl}$ fertilizers, SP-36 fertilizers, pesticides and labour could reduce total beans per $100 \mathrm{~g}$ of dry cocoa beans and (2) there was a correlation between total beans per $100 \mathrm{~g}$ of dry cocoa beans and total fat content. The more cocoa beans per $100 \mathrm{~g}$, the higher the total fat content. Farmers had to pay attention to the usage of input production such as fertilizers, pesticides and labour because it could increase the quality of cocoa beans.
\end{abstract}

Keywords: Input, Quality, Cocoa Beans

\section{Introduction}

The cocoa cropping condition in the region of Indonesia and specifically Central Sulawesi faced the problem of slowly degrading productivity and quality of its cocoa industry. Cocoa productivity in Central Sulawesi only reached a maximum of $670 \mathrm{~kg} \mathrm{~h}^{-1}$, whereas its genetic potential that was $1.8-2.75$ tonnes $\mathrm{ha}^{-1}$-a huge discrepancy (DPDJP, 2009). A decrease in productivity and quality affected the income of farmers, which reduced farmer enthusiasm for the crop, leading to a further decrease and quality and general slack in the industry as they attempted to replace cocoa with other commodities. This condition threatened the sustainability Indonesian cocoa. Efforts to increase cocoa crop productivity and the quality of cocoa beans which were produced by the farmers should therefore continue to be made.

The supply of qualified cocoa beans must be carried out at this time. This is due to the fact that the quality of beans greatly affects both the quality of final products and market price for cocoa and cocoa-related commodities. High quality cocoa beans must also be fermented, cleaned and dried (Sulistyowati and Wahyudi, 1999; Schwan and Wheals, 2004; Illeghems et al., 2012; Trognitz et al., 2013). Furthermore, physical characteristics, chemical and organoleptic factors affect the quality of cocoa beans (Wahyudi et al., 2008). Physical characteristics include the total beans per $100 \mathrm{~g}$, whether or not they are properly fermented, and the amount of moldy beans per 100 g. Chemical characteristics include total fat content and water content. Industry and consumers in developed countries are very much concerned about the usage of qualified raw materials (cocoa beans). Every effort of current cocoa production (cultivation) must pay attention to all factors that affect the quality of beans produced in order to gain the best compensation in global markets.

Several more components determine the quality of cocoa beans, such as the provision of input production, crop genetics, seasonal weather and maintenance/management. Input production, such as the number and quality, need to be known by a producer (farmer). Input production can be divided into two groups, namely biological factors, such as agricultural land and fertilizers (N, P and $\mathrm{K}$ ) and socio-economic factors such as labour; control of input production allows farmers to maximize the efficiency of crops and gain higher global market restitutions (Soekartawi, 2003).

Seasonal and genetic factors influence the fat content of cocoa beans (Mulato et al., 2009; Wahyudi et al., 2008). Mulato et al. (2009) stated that the type (clones) of crops, environmental conditions (rainfall) during fruit development, and agronomic conditions strongly influence the weight of the beans. This research aims to: (1) analyze the effects of input production on the total beans per $100 \mathrm{~g}$ of dry cocoa beans and (2) analyze the correlation of total beans and fat content of cocoa beans.

\section{Research Methods}

This research was conducted in the Palolo Sub-Regency Sigi Regency of Central Sulawesi. The villages of Sejahtera and Tongoa were the research locations. This is because these two villages are central areas of cocoa productions in Palolo Sub-Regency Sigi Regency. 
The research includes a total of 238 Household Heads (HH): 106 from Sejahtera Village and132 from Tongoa Village, respectively. The study calculates total samples by using Parel et al.'s (1973) formula:

$$
n=\frac{N \sum N_{h} s_{h}^{2}}{N^{2} \frac{d^{2}}{z^{2}}+\sum N_{h} s_{h}^{2}}
$$

Where:

$$
\begin{aligned}
& n=\text { Total samples } \\
& N=\text { Total populations } \\
& N_{h}=\text { Total populations in each village } \\
& d=\text { Precision was set at }=5 \% \\
& z=1.96(95 \%) \\
& s_{h}=\text { Variant of each village } \\
& n_{h}=\text { Total samples in each village }
\end{aligned}
$$

Total samples here involved $144 \mathrm{HH}$ from the villages.

This research used survey methods to determine sampling by probability with the Simple Random Sampling technique, which was a sampling technique done randomly against members of population. The formula determined sampling from each village proportionally:

$n_{h}=\frac{N_{h}}{N} n$

Where:

$n_{h}=$ Total samples in each village

$n=$ Total samples $=144 \mathrm{HH}$

$N=$ Total populations $=238 \mathrm{HH}$

$N_{h}=$ Total populations in each village

Sejahtera Village's sample involved $64 \mathrm{HH}$ and Tongoa Village contributed $80 \mathrm{HH}$.

\section{Total Fat Content}

Total fat content of cocoa beans was determined based on standard procedures carried out in the Laboratory of Post-Harvest Research Center of Coffee and Cocoa in Jember, Indonesia. Samples of cocoa beans were peeled, then grinded until the mixture reached a size of $150 \mu$. A total of $5 \mathrm{~g}$ of grinded beans were hydrolyzed using $\mathrm{HCl} 25 \%$ (w/w). Furthermore, the extraction of cocoa bean fats used non-polar organic solvents (petroleum benzene; boiling point 40$60^{\circ} \mathrm{C}$ ). Fat content is calculated as follows:

$$
\frac{100\left(M_{2}-M_{1}\right)}{M_{0}} \times \frac{100}{100-K_{A}}
$$

Where:

$M_{0}=$ Weight of samples $(\mathrm{g})$

$M_{1}=$ Weight of pumpkins and stones (g)
$M_{2}=$ Weight of pumpkins, stones and fat (g)

$K_{A}=$ Water content of samples

\section{Total Beans per $100 \mathrm{~g}$}

Weighing on the sample $(100 \mathrm{~g})$ followed by counting the total beans determined total beans per 100 g. The test results were set based on total beans in the sample $(100 \mathrm{~g})$ and stated: AA with a number of less than up to 85 beans; A with a number between $86-100$ beans; B with number between 101-110 beans; $C$ with number between 111-120 beans; and $\mathrm{S}$ with a number of more than 120 beans.

The Cobb-Douglas production function answers the first goal, where the function is transformed into a linear form of the natural logarithm as follows:

$$
\begin{aligned}
& \ln K=\beta_{0}+\beta_{1} \ln P U+\beta_{2} \ln P K C l \\
& +\beta_{3} \ln P S P 36+\beta_{4} \ln P E S T+\beta_{5} \ln T K+\varepsilon_{i}
\end{aligned}
$$

Where:

$$
\begin{array}{ll}
K & =\text { total beans per } 100 \mathrm{~g} \text { of cocoa beans (beans) } \\
P U & =\text { urea fertilizers }(\mathrm{kg}) \\
P K C l & =\mathrm{KCl} \text { fertilizers }(\mathrm{kg}) \\
P S P 36 & =\mathrm{SP}-36 \text { fertilizers }(\mathrm{kg}) \\
P E S T & =\text { pesticides (liter) } \\
T K & =\text { labors }(\text { day people working }=\mathrm{DPW}) \\
\varepsilon_{i} & =\text { Error }
\end{array}
$$

Correlation analysis of Product Moment is used to answer the second goal, with the formulation as follows:

$r_{K L}=\frac{n \sum K_{i} L_{i}-\left(\sum K_{i}\right)\left(\sum L_{i}\right)}{\sqrt{\left\{n \sum K_{i}^{2}-\left(\sum K_{i}\right)^{2}\right\}} \sqrt{\left\{n \sum L_{i}^{2}-\left(\sum L_{i}\right)^{2}\right\}}}$

$L=$ Total fat content $(\%)$

\section{Results}

The Effect of Input against Total Beans per $100 \mathrm{~g}$ of Cocoa Beans

This study uses multiple regression analysis to analyze the effects of input production against total beans per 100 $\mathrm{g}$ of dry cocoa beans. Urea fertilizers, $\mathrm{KCl}$ fertilizers, SP36 fertilizers, pesticides and labour encompass this research's definition of input production. Results of multiple regression analysis are shown on Table 1.

\section{Correlation of Total Beans per $100 \mathrm{~g}$ of Dry Cocoa Beans with Total Fat Content}

Product moment correlation analysis provided an avenue to analyze the correlation between total beans per $100 \mathrm{~g}$ of dry cocoa beans versus total fat content. The results of product moment correlation analysis showed the value of 0.932 or $93.20 \%$. 
Table 1. Estimation of regression coefficients

\begin{tabular}{|c|c|c|c|c|c|}
\hline Model & Regression coefficients & Standard error & $\mathrm{t}$ & Sig. & VIF \\
\hline (Constant) & 4.909 & & & & \\
\hline Urea Fertilizers (PU) & -0.009 & 0.002 & $-4.636^{*}$ & 0.000 & 3.711 \\
\hline $\mathrm{KCl}$ Fertilizers (PKCl) & -0.012 & 0.002 & $-6.825 *$ & 0.000 & 3.061 \\
\hline SP-36 Fertilizers (PSP36) & -0.019 & 0.001 & $-14.156^{*}$ & 0.000 & 1.856 \\
\hline Pesticides (PEST) & -0.013 & 0.001 & $-10.375^{*}$ & 0.000 & 1.587 \\
\hline Labors (TK) & -0.017 & 0.001 & $-16.191^{*}$ & 0.000 & 1.168 \\
\hline
\end{tabular}

* Significant at $\alpha 5 \%$

\section{Discussion}

Adjusted $\mathrm{R}^{2}$ was 0.831 , showing that variation of total beans per $100 \mathrm{~g}$ of dry cocoa beans (cocoa beans quality) can be explained by the independent variable of Urea fertilizers, $\mathrm{KCl}$ fertilizers, SP-36 fertilizers, pesticides and labour simultaneously-as many as $83.10 \%$. At the same time, the remaining $16.90 \%$ are explained by other factors not included in the model. The effects of each factor against the quality of cocoa beans are as follows.

The usage of Urea fertilizers had significant negative effects on total beans per $100 \mathrm{~g}$ of dry cocoa beans, where t-count $=-4.636$ with probability $0.000<0.05(\alpha$ $5 \%)$ two-tail test. Elasticity -0.009 means that every increase in Urea fertilizers, even $1 \%$, reduces total beans in $100 \mathrm{~g}$ of dry cocoa beans as much as $0.009 \%$. This is done by assuming other factors considered are constant. It showed that the usage of Urea fertilizers on cocoa crops could cause cocoa beans to grow larger and become more solid, so total beans reduced per $100 \mathrm{~g}$ of dry cocoa beans. This research is relevant to the research of Sokri et al. (2013), where nitrate had effects on fruit ripening. This makes sense, as Nitrogen $(\mathrm{N})$ is the primary nutrient for crops and important for all organisms (Vrede et al., 2004).

The usage of $\mathrm{KCl}$ fertilizers had significant negative effects on total beans per $100 \mathrm{~g}$ of dry cocoa beans, where t-count $=-6.825$ with probability $0.000<0.05(\alpha$ $5 \%)$ two-tail test. This elasticity of -0.012 means that every increase in $\mathrm{KCl}$ fertilizers, as many as $1 \%$, could reduce the total beans in $100 \mathrm{~g}$ of dry cocoa beans as much as $0.012 \%$. This assumes that other factors were constant. It showed the usage of $\mathrm{KCl}$ fertilizers on cocoa crops could cause cocoa beans to become bigger and solid so that total beans reduced per $100 \mathrm{~g}$ of dry cocoa beans. Potassium (K) plays a key role in osmoregulation, the regulation of stomata, photosynthesis and cell extension (Porras-Soriano et al., 2009). Adding higher K uptake can help to mitigate salt stress in crops (Thomas et al., 2003).

The usage of SP-36 fertilizers had significant negative effects on total beans per $100 \mathrm{~g}$ of dry cocoa beans, where t-count $=-14.156$ with probability $0.000<0.05(\alpha 5 \%)$ two-tail test. An elasticity of -0.019 means that every increase in SP-36 fertilizers, so far as much as $1 \%$, could reduce the total beans in $100 \mathrm{~g}$ of dry cocoa beans as much as $0.019 \%$, so long as research assumes other factors are constant. It showed the usage of SP-36 fertilizers on cocoa crops could cause cocoa beans to grow larger and far more solid so that total beans reduced per $100 \mathrm{~g}$ of dry cocoa beans. Phosphorus $(\mathrm{P})$, the primary nutrient for crops and important for all organisms (Vrede et al., 2004), is an important element in the production of ribosomes (Agren, 2008). Protein synthesis requires $\mathrm{P}$ in promoting growth (Elser et al., 2000; Hessen et al., 2007). However, excessive usage of organic $\mathrm{P}$ can cause suppression of the Arbuscular Mycorrhizal Fungi (AMF) community (Jordan et al., 2000). AMF has been proven to increase crop growth and production by increasing nutrient uptake in various agroeco systems (Sensoy et al., 2007; Meghvansi et al., 2008).

The usage of pesticides had significant negative effects on total beans per $100 \mathrm{~g}$ of dry cocoa beans, where t-count $=-10.375$ with probability $0.000<0.05(\alpha$ $5 \%$ ) two-tail test. Elasticity -0.013 is definable by every usage of pesticides on crops attacked by pests and diseases, as many as $1 \%$. These could reduce the total beans in $100 \mathrm{~g}$ of dry cocoa beans by as many as $0.013 \%$, so long as the equation assumes other factors are constant. These results showed that the usage of pesticides on cocoa crops attacked by pests and diseases could cause cocoa beans to malform. Cocoa beans that grew in a healthy manner enlarge and increase in solidity so total beans decreased per $100 \mathrm{~g}$ of dry cocoa beans. However, excessive usage of pesticides can cause disease in humans, endangering the local population (Slusky et al., 2012; Navaranjan et al., 2013).

The usage of labour had significant negative effects on total beans per $100 \mathrm{~g}$ of dry cocoa beans, where tcount $=-16.191$ with probability $0.000<0.05(\alpha 5 \%)$ twotail test. This elasticity -0.017 could be defined to mean every increase in labour on cocoa crops, as much as $1 \%$, could reduce the total beans in $100 \mathrm{~g}$ of dry cocoa beans as much as $0.017 \%$, by assuming other factors remained constant. It showed that variations in the usage of labour in cocoa crops could cause cocoa beans to enlarge and become more solid so that total beans reduced per $100 \mathrm{~g}$ of dry cocoa beans. Input usage improved with increases in labour investment, so the nutrient needs were fulfilled. This research is relevant to Li et al. (2008), who stated labour correlate positively with agricultural production. 
The correlation coefficient 0.932 meant the correlation of total beans per $100 \mathrm{~g}$ of dry cocoa beans with total fat content was very strong. The fewer total beans per $100 \mathrm{~g}$ of dry cocoa beans or the greater cocoa beans then the higher total fat content. Additionally, the usage of fertilizers heavily influenced the largeness and density of cocoa beans, showing that this is one the factors that should be considered by farmers in order to increase the total fat content of cocoa beans. This would result in better market prices and improve the attractiveness of cocoa beans as a crop.

The results showed that the average of total beans per $100 \mathrm{~g}$ of dry cocoa beans was 136 beans and average of total fat content was $45.46 \%$. Total fat content was still less when compared with fat content of the previous research results, which was as much as $50-57 \%$ (Hannum and Erdman Jr, 2000). The average of total beans per $100 \mathrm{~g}$ of cocoa beans in this research fell into category $\mathrm{S}$, which meant the quality of cocoa beans was still low.

\section{Conclusion}

Urea fertilizers, $\mathrm{KCl}$ fertilizers, SP-36 fertilizers, pesticides and labour could reduce total beans per $100 \mathrm{~g}$ of dry cocoa beans. There was a correlation between total beans per $100 \mathrm{~g}$ of dry cocoa beans and total fat content. The more cocoa beans per $100 \mathrm{~g}$, the higher the total fat content. Farmers had to pay attention to the usage of input production such as fertilizers, pesticides and labour because it could increase the quality of cocoa beans.

\section{Acknowledgment}

The authors would like to thank the Director General of Higher Education Indonesia (DIKTI), which had helped fund this research through DP2M in 2015. The authors also thanks the reviewers who had took time to perfect this article.

\section{Author Contribution}

Effendy and Made Antara were together designed the research, analyzed data and wrote the paper.

\section{Ethics}

This paper is original and authors confirm that all of other authors have read and approved the paper.

\section{References}

Agren, G.I., 2008. Stoichiometry and nutrition of plant growth in natural communities. Annu. Rev. Ecol. Evol. Syst., 39: 153-170.

DOI: 10.1146/annurev.ecolsys.39.110707.173515

DPDJP, 2009. Buku panduan teknis budidaya tanaman kakao (Theobroma cacao L.). Departemen Pertanian Direktorat Jenderal Perkebunan (DPDJP).
Elser, J.J., R.W. Sterner, E. Gorokhova, W.F. Fagan and T.A. Markow et al., 2000. Biological stoichiometry from genes to ecosystems. Ecol. Lett., 3: 540-550. DOI: $10.1111 /$ j.1461-0248.2000.00185.x

Hannum, S.M. and J.W. Erdman Jr, 2000. Emerging health benefits from cocoa and chocolate. J. Med. Food, 3: 73-75. DOI: 10.1089/109662000416276

Hessen, D.O., T.C. Jensen, M. Kyle and J.J. Elser, 2007. RNA responses to $\mathrm{N}$ - and P-limitation; reciprocal regulation of stoichiometry and growth rate in Brachionus. Functional Ecol., 21: 956-962. DOI: $10.1111 /$ j.1365-2435.2007.01306.x

Illeghems, K., L.D. Vuyst, Z. Papalexandratou and S. Weckx, 2012. Phylogenetic analysis of a spontaneous cocoa bean fermentation metagenome reveals new insights into its bacterial and fungal community diversity. PLoS ONE, 7: 1-11. DOI: $10.1371 /$ journal.pone.0038040

Jordan, N.R., J. Zhang and S. Huerd, 2000. Arbuscularmycorrhizal fungi: Potential roles in weed management. Weed Res., 40: 397-410. DOI: $10.1046 /$ j.1365-3180.2000.00207.x

Li, X., Y. Luo, Q. Gao, S. Dong and X. Yang, 2008. Farm production growth in the upper and middle parts of the Yellow River Basin, China, During 1980-1 999. Agric. Sci. China, 7: 344-355. DOI: 10.1016/S1671-2927(08)60075-9

Meghvansi, M.K., K. Prasad, D. Harwani and S.K. Mahna, 2008. Response of soybean cultivars toward inoculation with three arbuscular mycorrhizal fungi and Bradyrhizobium japonicum in the alluvial soil. Eur. J. Soil Biol., 44: 316-323. DOI: 10.1016/J.EJSOBI.2008.03.003

Mulato, S., S. Widyotomo, Misnawi and E. Suharyanto, 2009. Petunjuk teknis pengolahan produk primer dan sekunder kopi pusat penelitian kopi dan kakao Indonesia. Jember.

Navaranjan, G., K. Hohenadel, A. Blair, P.A. Demers and J.J. Spinelli et al., 2013. Exposures to multiple pesticides and the risk of hodgkin lymphoma in canadian men. Cancer Causes Control, 24: 1661-1673. DOI: $10.1007 / \mathrm{s} 10552-013-0240-\mathrm{y}$

Parel, C.P., G.C. Caldito, P.L. Ferrer, G.G. De Guzman and C.S. Sinsioco et al., 1973. Sampling Design and Procedures. 1st Edn., The Agricultural Development Council. Quezon City, pp: 53.

Porras-Soriano, A., M.L. Soriano-Martı'n, A. PorrasPiedra and R. Azco'n, 2009. Arbuscular mycorrhizal fungi increased growth, nutrient uptake and tolerance to salinity in olive trees under nursery conditions. J. Plant Physiol., 166: 1350-1359. DOI: 10.1016/j.jplph.2009.02.010

Schwan, R.F and A.E. Wheals, 2004. The microbiology of cocoa fermentation and its role in chocolate quality. Critical Rev. Food Sci. Nutrition, 44: 205-221. DOI: $10.1080 / 10408690490464104$ 
Sensoy, S., S. Demir, O. Turkmen, C. Erdinc and O.B. Savur, 2007. Responses of some different pepper (Capsicum annuum L.) genotypes to inoculation with two different arbuscular mycorrhizal fungi. Scientia Horticulturae, 113: 92-95. DOI: $10.1016 /$ j.scienta.2007.01.023

Slusky, D.A., C. Metayer, M.C. Aldrich, M.H. Ward and C.S. Lea et al., 2012. Reliability of maternal-reports regarding the use of household pesticides: Experience from a case-control study of childhood leukemia. Cancer Epidemiol., 36: 375-380. DOI: 10.1016/j.canep.2011.12.009

Soekartawi, 2003. Teori ekonomi produksi dengan pokok bahasan analisis fungsi cobb-douglas. PT Raja Grafindo Persada, Jakarta.

Sokri, S.M., M. Babalar, H. Lesani and M. Asgari, 2013. The effect of different $\mathrm{NO} 3-/ \mathrm{NH} 4+$ ratio on qualitative and quantitative characteristics of apple fruit cultivars gala and golab. Ann. Nutrition Metabolism, 63: 259-259.

Sulistyowati and T. Wahyudi, 1999. Pengendalian mutu kopi dan kakao berdasarkan sistem standarisasi nasional. Warta Pusat Penelitian Kopi dan Kakao, 15: $203-220$
Thomas, J.M.G., K.J. Boote, L.H. Allen, M. GalloMeagher and J.M. Davis, 2003. Elevated temperature and carbon dioxide effects on soybean seed composition and transcript abundance. Crop Sci., 43: 1548-1557. DOI: 10.2135/cropsci2003.1548

Trognitz, B., E. Cros, S. Assemat, F. Davrieux and N. Forestier-Chiron et al., 2013. Diversity of cacao trees in waslala, nicaragua: Associations between genotype spectra, product quality and yield potential. PLoS ONE, 8: 1-13.

DOI: 10.1371/journal.pone.0054079

Vrede, T., D.R. Dobberfuhl, S. Kooijman and J.J. Elser, 2004. Fundamental connections among organism $\mathrm{C}: \mathrm{N}: \mathrm{P}$ stoichiometry, macromolecular composition and growth. Ecology, 85: 1217-1229. DOI: $10.1890 / 02-0249$

Wahyudi, T., T.R. Panggabean and Pujiyanto, 2008. Panduan lengkap kakao: Manajemen agribisnis dari hulu hingga hilir. Penebar Swadaya, Jakarta. 